\title{
Three-dimensional modeling of Eagle syndrome
}

Figure 1 CT angiography of styloid-carotid artery syndrome
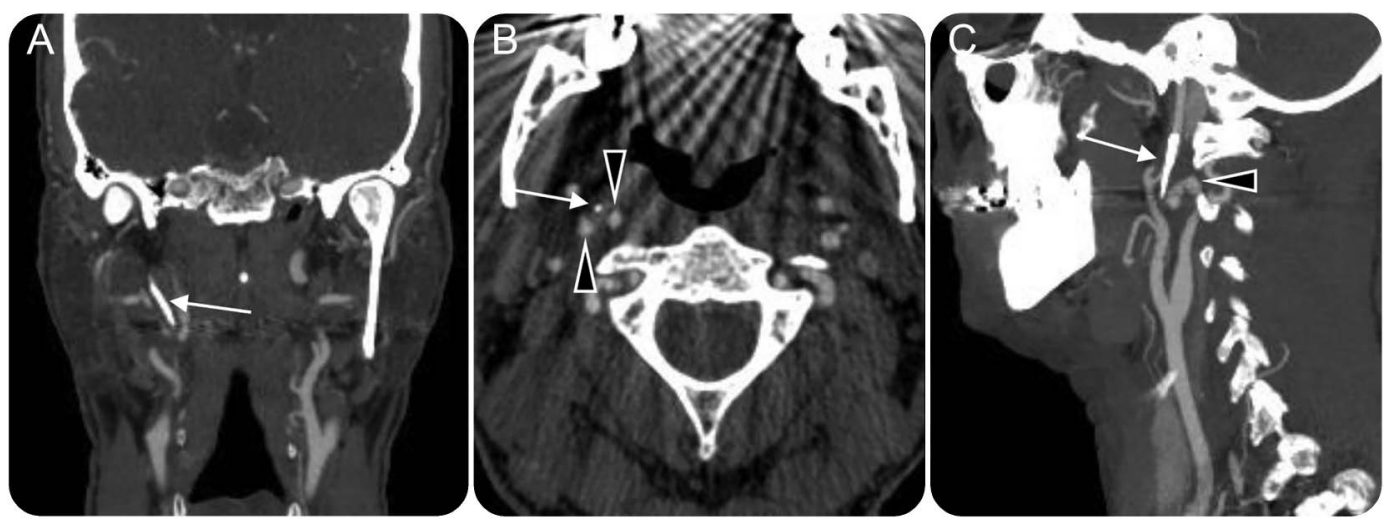

Coronal (A), axial (B), and sagittal (C) maximum intensity projection shows the elongated right styloid process (arrows, A-C) along with the tortuous right internal carotid artery (arrowheads, B and C).

A 63-year-old man presented with transient episodes of left-hand weakness and right-eye vision loss following a lengthy airplane trip. The patient had reported right neck pain after sleeping awkwardly on the flight. Carotid dissection, paradoxical embolism, atherosclerotic occlusion, and thrombotic occlusion were considered possible etiologies of the associated carotid occlusion. Following a period of anticoagulation, a subsequent CT angiography (figure 1, A-C) revealed findings consistent with the styloid-carotid artery, or Eagle, syndrome. ${ }^{1} \mathrm{~A}$ 3-dimensional model was subsequently created (figure 2, A and B) utilizing a 3D printer, which provided the most versatile, safe, and cost-efficient option ${ }^{2}$ to visualize the patient's unique anatomy and plan for surgical intervention.

Figure 2 Three-dimensional model of Eagle syndrome
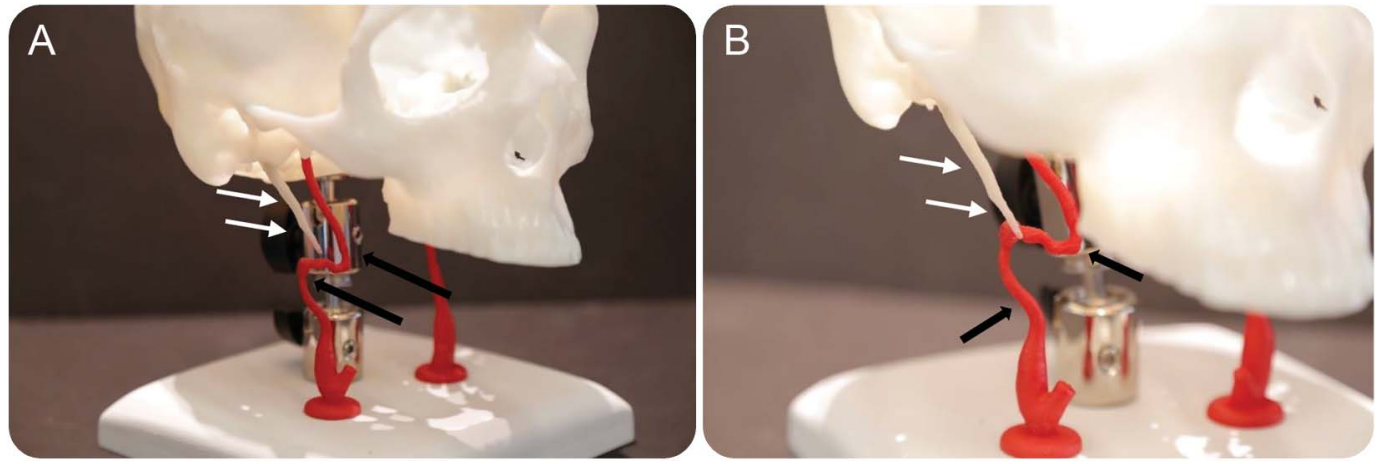

This flexible 3-dimensional model (A and B), created from CT angiography data, allowed for unrestricted manipulation of the patient's skull and experimentation with various head and neck positions to evaluate the interaction between the elongated styloid process (white arrows, A and B) and right internal carotid artery (black arrows, A and B). This precluded the need for additional angiography. 
Kavit Shah, MD, Daniel J. Miller, MD

From the Department of Neurology, Henry Ford Hospital, Detroit, MI.

Acknowledgment: The authors thank Eric Myers of the Henry Ford Innovation Institute for rendering of the 3D model.

Author contributions: Kavit Shah: acquisition of data, manuscript drafting, and manuscript revision. Daniel J. Miller: study concept and design, acquisition of images and model, critical revision of manuscript.

Study funding: No targeted funding reported.

Disclosure: The authors report no disclosures relevant to the manuscript. Go to Neurology.org for full disclosures.

Correspondence to Dr. Shah: Kshah8@hfhs.org

1. Eagle WW. Symptomatic elongated styloid process: report of two cases of styloid process-carotid artery syndrome with operation. Arch Otolaryngol 1949;49:490-503.

2. Preece D, Williams SB, Lam R, Weller R. "Let's get physical": advantages of a physical model over 3D computer models and textbooks in learning imaging anatomy. Anat Sci Educ 2013;6:216-224.

\section{Subspecialty Alerts by E-mail!}

Customize your online journal experience by signing up for e-mail alerts related to your subspecialty or area of interest. Access this free service by visiting Neurology.org/site/subscriptions/etoc.xhtml or click on the "E-mail Alerts" link on the home page. An extensive list of subspecialties, methods, and study design choices will be available for you to choose from—allowing you priority alerts to cutting-edge research in your field!

\section{Applications Now Open for 2017 Diversity in Leadership Program}

Applications are now open for the prestigious 2017 AAN Diversity in Leadership Program, which seeks to identify, orient, and cultivate high-potential members from diverse and underrepresented ethnic backgrounds who will be lifetime, engaged contributors to the American Academy of Neurology. View qualifications and apply before the December 10 deadline at AAN.com/view/DiversityLeadershipProgram.

\section{WriteClick ${ }^{\circledR}$ rapid online correspondence}

Have a comment on a recent $N$ eurolog $y^{\circledR}$ article you would like to share? Now it is easier and more convenient. Neurology.org has launched WriteClick on the home page and sidebars of each article to encourage remarks and debate among users.

WriteClick is restricted to comments about studies published in Neurology within the last eight weeks.

Learn more at Neurology.org/letters 


\title{
Neurology
}

\author{
Three-dimensional modeling of Eagle syndrome \\ Kavit Shah and Daniel J. Miller \\ Neurology 2016;87;2279-2280 \\ DOI 10.1212/WNL.0000000000003365
}

This information is current as of November 21, 2016

$\begin{array}{ll}\begin{array}{l}\text { Updated Information \& } \\ \text { Services }\end{array} & \begin{array}{l}\text { including high resolution figures, can be found at: } \\ \text { http://n.neurology.org/content/87/21/2279.full }\end{array} \\ \text { References } & \text { This article cites } 2 \text { articles, } 0 \text { of which you can access for free at: } \\ & \text { http://n.neurology.org/content/87/21/2279.full\#ref-list-1 } \\ \text { Subspecialty Collections } & \text { This article, along with others on similar topics, appears in the } \\ & \text { following collection(s): } \\ & \text { All Cerebrovascular disease/Stroke } \\ \text { http://n.neurology.org/cgi/collection/all_cerebrovascular_disease_strok } & \text { e } \\ & \text { All Clinical Neurology } \\ & \text { http://n.neurology.org/cgi/collection/all_clinical_neurology } \\ & \text { All Education } \\ \text { http://n.neurology.org/cgi/collection/all_education } & \text { All Headache } \\ \text { http://n.neurology.org/cgi/collection/all_headache } \\ \text { Information about reproducing this article in parts (figures,tables) or in } \\ \text { its entirety can be found online at: } \\ \text { http://www.neurology.org/about/about_the_journal\#permissions } \\ \text { Permissions \& Licensing } \\ \text { Information about ordering reprints can be found online: } \\ \text { http://n.neurology.org/subscribers/advertise }\end{array}$

Neurology ${ }^{\circledR}$ is the official journal of the American Academy of Neurology. Published continuously since 1951, it is now a weekly with 48 issues per year. Copyright @ 2016 American Academy of Neurology. All rights reserved. Print ISSN: 0028-3878. Online ISSN: 1526-632X.

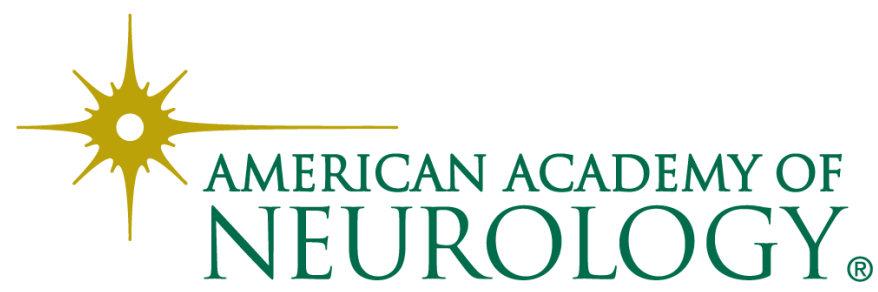

